\title{
Institutional Development of Contemporary Art in Ukraine. Activity of CCA «Soviart»
}

\author{
ANNA LUHOVSKA \\ Graduate student, The National Academy of Visual Arts and Architecture \\ orcid.org/0000-0002-9089-5885
}

\begin{abstract}
At the beginning of the third decade of the 21st century, we see an increase in the activity of art institutions in Ukraine. We are already accustomed to their large number and to their diversity. However, talking about independent institutions, it should be remarked that they did not exist at all until recent times (late 1980s and early 1990s). The pioneer in this field was CCA (Center of the contemporary art) "Soviart" - the first independent art institution in Ukraine (which from its emersion worked on the completely new, western model) that greatly influenced the formation and further development of contemporary art in our country. The article thoroughly analyzes its activities, examines the experience of exhibitions, art festivals and artistic projects both in Ukraine and abroad. It explores the examples of successful international cooperation, collaboration with other institutions and embassies, which has change to foster cultural dialogue with other countries. Analyzing CCA "Soviart", we can observe the circumstances under which non-state art institutions were born as a result of the collapse of the USSR and gaining of independence in Ukraine. The article helps to understand the processes that became crucial for the contemporary art in Ukraine, especially on the examples of first art fairs and festivals. It gives the understanding that the era of total financial support from the government and state budget was over and the alternative ways for successful functioning (such as involvement of investors and grant programs) should be found. After all, an art institution is not just walls, it is about people, who create conditions (art projects, exhibitions, festivals, research), which is a powerful stimulus for the emergence of a cultural product and the successful development of culture in general.
\end{abstract}

Keywords: Art institution, activity of the center of contemporary art "Soviart", contemporary art, art project, exhibition, art festival.

Formulation of the problem. The relevance of the study lies in rethinking the socio-political processes in Ukraine in the early 1990s. It led to the transformation of artistic infrastructure against the background of reduced state control and the formation of the private sector what became possible due to such changes.

Analysis of recent researches and publications. Studies of Ukrainian scientists such as O. Avramenko, N. Bulavin, K. Malykh, L. Smyrna, O. Petrova, L. Herman, V. Sidorenko are devoted to the problems of origin and development of art infrastructure in the artistic space of the country. In the global context, this issue was considered by B. Groys, P. O’Neill, H. Obrist, T. Smith.

The purpose of the article is to explore the circumstances and processes that influenced the further development of art in Ukraine through the prism of one art institution. In order to better understand the whole situation, it is necessary to outline a complete picture of what happened in the analyzed period

Presentation of the main research material. Globalization processes in modern society have led to the appearance of a complex institutional mech- 
anism. It has comprehensively developed through the daily work of many people: who create a cultural product, organize exhibitions, art projects, festivals, write about art and research it, print catalogs, booklets, posters, etc. All these exist in order for culture not to focus solely on artists, but to be the property of the whole society.

The institution objectively emerges at the «assembly point» of ideas, performers and resources for their implementation. At the same time it is a platform for the demonstration of artworks, a form of relationship, a means of communication between all participants in the art scene and, a powerful tool for influencing the development of art.

In the non-state sector of Ukraine, the development of the institutional process was motivated by the crisis of public sector reform and the emergence of conditions for its alternative. When the first non-governmental institution in the field of art - the Center of Contemporary Art (CCA) "Soviart" - began its activities in 1987, there was almost no competition in this field. CCA demonstrated a completely new for the local context model of presentation of art within the program-targeted activities, based on foreign experience of innovative project and work presentation. Soviart, through developing the priority directions of the contemporary art became the organizer of a large number of projects of non-figurative art, land art, photography, street art, media art festivals, exhibitions, art schools, publishing projects both in Ukraine and abroad. Over the years of its existence, CCA has been the organizer and participant of art projects in Georgia, Denmark, Estonia, Italy, Lithuania, Germany, UAE, Russia and the USA.

The investment platform for all promising cultural and artistic practices of "Soviart" was the scientific and technical firm "Ivrus", whose founder and CEO was V. Khamatov. Founded in 1988, it has gone from being the first in USSR scientific and technical youth center to the investment corporation with many branches and partners. It was its financial potential that was involved in the circulation of art projects [5].

In line with our study, it should be noted that the starting point for the future CCA «Soviart» was the All-Ukrainian Festival of Creative Youth — «Youth Crossroad», whose founders was a group «Quantum» led by V. Khamatov in 1985 . The festival covered theater, music (including rock music) and fine arts. In 1986-1987, the festival program already included joint art exhibitions: Kyiv-Kaunas and KyivTallinn, where O. Holosiy and many other young artists of the 1980s took part from the Ukrainian side. The curator of the exhibitions was S. Sviatchenko, the future art director of CCA «Soviart», and at that time - the art editor-in-chief of the youth magazine «Ranok» (the information partner of the festival). CCA "Soviart" was established on a voluntary basis with premises on 11/11 Vasylkivska Street in 1987. Before the proclamation of Ukraine's independence in 1991, CCA "Soviart" went through institutional changes from a youth organization in 1987, a creative cooperative in 1988 (founders V. Khamatov, S. Svyatchenko, V. Yatsenko, Y. Pleskonos) to a public organization in 1990.

Since its establishment in 1987, CCA "Soviart" has chosen contemporary visual art as a priority area of socio-cultural investments. By 1988, an ambitious strategy was developed to reach the level of Western European and American centers of contemporary art.

The first step of the strategy was a Soviet-American exhibition, which aimed not just to present the works of young artists from both countries, but to establish creative contacts that arose during the joint work on the project [11]. Having found American partners, CCA representatives agreed to cooperate with them on the implementation of a number of joint projects. They were also supported by the US Embassy in Moscow and public institutions such as Ukrainian Artists' Association.

For Ukrainian artists, who were in a certain artistic vacuum, it was a useful communicative experience: to work with foreign artists, to see what the contemporary art of a capitalist country is, which had the status of bourgeois and declining in the USSR. Only six months passed from the origin of the idea to its realization. This is a very short period of time, because American partners faced a number of challenges: to gather experts, to apply for the grant to foundations and to find 
a curator. The event was organized by the American company Global Concept and CCA "Soviart" in cooperation with the youth section of the Union of Soviet Artists of Ukraine (Ukrainian Artists' Association). On the Ukrainian side, the selection process was led by "Soviart" Art Director S. Sviatchenko in collaboration with foreign partners. At this time he also actively cooperated with the associations of artists of Ukraine, Lithuania, Latvia and Estonia. This was the first international exhibition lasting a year and a half, which was exhibited in other republics and outside the USSR. The project also gave the first experience of receiving a grant in the field of art through an American partner of up to 40 thousand dollars (the cost of a competition for the selection of works, the travel expenses of American artists with their stay in Moscow and Kyiv, etc.).

«Soviart» thoroughly approached both the organization of advertising (booklets, T-shirts, badges, packages including the logo that was specially developed for this purpose by S. Sviatchenko) and information support, which, in fact, was a new project approach in the field of presentation of Ukrainian art [12].

The grand opening took place in October 1988 in the exhibition hall of the Artists Association at 51/53 Volodymyrska Street. Success was evidenced by the large number of people wishing to attend the event; and this is despite the cost of the ticket -1 ruble (big money at the time), because the project was conceived as a commercial from the very beginning. At the end of the tour, the organizers received 200,000 rubles (the official rate at that time was 1 dollar -74 coins). Such success was difficult to compare with anything, since this commercial format has not yet existed.

After the successful Soviet-American exhibition, Soviart continued to work on international art projects, presenting Ukrainian art abroad - something that artists could not have dreamed of 5-10 years ago. This was facilitated by the establishment of official links between the twin cities of Kyiv and Odense (Denmark), initiated by Soviart and supported by the resources of the "Irvus" Corporation. The first exhibition was — «21 view (sight). Young Contemporary Ukrainian Artists" (1989), which was attended by young and now well-known representatives of the "New Wave" of Ukrainian art. The exhibition was presented in Kyiv - at the exhibition hall of the Association of Artists on Volodymyrska Street, and then in Denmark - in the city hall of Odense [5].

Presentation activities were gaining momentum, the circle of international partners was expanding. In 1990, Soviart presented another successful project “Ukrainian MalARTstvo (1960-1980)", curated by art critics G. Sklyarenko, O. Kuzyants, and S. Sviatchenko. The exhibition took place in January 1990 in the Chamber of Commerce on Lviv Square in Kyiv, and later in Copenhagen and Odense in Denmark. The exhibition, attended by 59 artists, was the result of cultural relations between the twin cities (of Kyiv and Odense) for the second time. The project was dedicated to alternative Ukrainian art of three decades. The characteristics of this period and the thoughts about the exhibition presented in the preface to the catalog by the famous art critic G. Sklyarenko were quite interesting: "Paradoxically, but perhaps the most mysterious and unknown in our fine arts was the period of 19601980. It was a time, when a kind of two-layered artistic life was formed, in which numerous exhibitions reflected only one, the "upper», officially encouraged way of developing art, the other, «deep», which did not fit into the conventional framework, remained out of viewers and critics. 1987 was a turning point for Ukraine in this respect (The exhibition «Ukrainian painting (60-80 years)», organized by the Center for Contemporary Art «Soviart» in 1990, was the first attempt to fill this gap «[7, p. 8-21].

The above-mentioned events took place against the background of the processes of "perestroika" (rebuilding) and publicity in the USSR, when the weakening of state control in all spheres contributed to the irreversibility of the emergence of modern art on the surface of artistic life. According to art critic L. Smyrna, «Soviart» has demonstrated in Ukraine and abroad a successful private, public, institutional non-governmental alternative to the conservative public sector of culture and the benefits of the project approach» [8, p. 191]. 
Among the exhibitions of Ukrainian art, which were also exhibited in Denmark, it is worth mentioning «Gold of the Scythians» (1993) and «Ukrainian Classical Avant-Garde» (1996), held together with the National History and National Art Museums, where western viewer could have seen old and new traditions of Ukrainian visual culture [9]. Projects of this level were implemented for the first time in Ukraine «from nail to nail» by a non-governmental institution, which set an important precedent for further public-private partnership.

Since 1995, Soviart has organized and held numerous exhibitions with the participation of foreign embassies. The Graphic Symposium with the America House (1995), art exhibitions with the French Cultural Center (1998), with the embassies of Canada, Macedonia, Armenia (2000), with the embassies of Egypt, USA and Poland (2000-2005) [9].

Another area of Soviart's activity was gallery activity. In general, at the beginning of the 1990s, there were almost no private galleries in Ukraine, as institutional activities in independent Ukraine began to gain momentum only in the mid-1990s. [12]. The impetus for their formation were the Kyiv Art Fairs organized in the Ukrainian House in 1994-1995. This was the first experience of organizing such events, so they differed from Western analogs of that time. A significant problem was the sale of artworks, which was necessary to reimburse the cost of renting boxes for the galleries and to stimulate their development. The head of the exhibition directorate of the National Association of Artists of Ukraine O. Solovyov, together with the participants of «Parkomuna» created the project «Permanent Revolution» on the fifth floor of the Ukrainian House, where the artworks were exhibited behind a bright orange fence. At the same time, on the first and second floors there were numerous galleries, most of which disappeared without leaving a trace in history. CCA «Soviart» was also presented at this fair. It represented artists with whom it had already worked on the project « 21 view (sight). Young contemporary Ukrainian artists» (1989).

After the second art fair in 1995, a press conference was held, at which representatives of the par- ticipating galleries noted the low level of management, advertising campaigns, publishing products, and resource provision. CCA «Soviart» with a group of partners (corporation «Iris» (V. Yatsenko), gallery «World L» (L. Avramenko), etc.) initiated the creation of the Association of Art Galleries of Ukraine for art creation of festivals, coordination of activities in Ukraine and abroad of non-state sector of visual fine arts, development of contemporary art, communication with the public sector of culture of Ukraine.

On September 27, 1995, at the founding conference, which took place at the pavilion of the Iris Corporation at the EANE, the Association of Art Galleries of Ukraine was launched. Its founders were 27 galleries which elected V. Khamatov for the post of the president. In total, at the time of the Association's establishment, there were about 35 galleries in Ukraine. CCA «Soviart» organizationally and resourcefully became the operator of projects and programs of the Association, whose activities were based on a voluntary basis, without membership fees, in partnership in its program projects.

In order to develop and promote gallery activities, the Association of Art Galleries, with the support of the Ministry of Culture and Arts of Ukraine, the Ukrainian Cultural Foundation and other partners, founded the International Art Festival in 1996, which operated annually until 2002 in Ukrainian House. The First International Art Festival in June 1996 brought together a large number of galleries, each of which presented its own artistic content. The success of the event inspired the organizers to continue, and the following year (1997) the II International Art Festival took place, which was remembered by the exhibition of artists from the twin cities of Kiev - Odense (Denmark) and Toulouse (France).

Creative connections continued to be established with other countries. Thus, at the III International Art Festival in June 1998, a high-profile International Biennial of Non-Figurative Painting and the exhibition «Image of the Enemy» took place - as a part of the program of Ukrainian-German cooperation. The largescale project «Art of Ukraine of the XX Century», which took place under the patronage of the Presi- 
dent of Ukraine Leonid Kuchma, consisted of 12 exhibitions: in addition, the first festival of video art «Dream Trap» was held as part of the event.

Five art festivals between 1996 and 2000 completed the mixed model format, when alongside the gallery presentations of individual artists, creative associations, and an art fair, non-profit projects and pilot models were presented. In the future it was planned to have a model of the festival exclusively of contemporary art projects. And this plan was realized in festivals such as «Initiative I» and «Initiative II» that took place in 2001 and 2002 in the Ukrainian House and a number of venues in the city (Lavra Gallery, Ukrkinochronika studio garage, CCA “Soviart” Gallery, Central Park, etc.).

Summing up the results of international art festivals, it should be noted that for Kyiv at that time it was really significant phenomenon. Creative projects of galleries and artists from different cities of Ukraine, as well as exhibitions from other countries were presented here.

The festival «Cultural Heroes» became a pilot innovation in the development of creative processes in the regions of the country. The Association of Art Galleries of Ukraine together with the TV company «Inter» and the Association of Contemporary Artists on the initiative of M. Gelman and his creative team held the festival «Cultural Heroes» in 2002. It took place in Kyiv, Kharkiv, Odesa, Lviv, IvanoFrankivsk, Dnipro and Donetsk, combining theater, literature, music and fine arts. According to the producer of the project V. Khamatov, the event that was conceived as a slice of modern urban culture, has grown into an unprecedented marathon - a presentation of the modern cultural potential of the regions of Ukraine [13, p. 11]. The Festival "Cultural Heroes", with its art marathon of cities - the main cultural centers of Ukraine - actually opened the door to contemporary art for the «generation of zeros».

Completing the institutional cycle of development with the project «Art of Ukraine of the $20^{\text {th }}$ Century», «Soviart» on the basis of its collection of contemporary art, existing infrastructure and art directorate, together with a group of art critics, curators and artists, founded the first non-governmental museum of contemporary art in Ukraine in 2003 at the authorized Ministry of Culture of Ukraine and approving the program of its activity. Currently there is a threefold structure: CCA «Soviart», Museum of Contemporary Art «Soviart», the Association of Art Galleries of Ukraine, specializing in various types of projects.

Thus, Soviart implemented a project model of a nongovernmental museum of contemporary art. In the context of digitalization, cultural transformations and financial globalism, this model has prospects in the development of the private sector of contemporary art. In fact, many other institutions in Ukraine have followed this path (Plast-Art in Chernihiv and multiple CCA in the regions).

Observing the emergence and development trends of galleries and institutions in Ukraine over the past few decades, CCA «Soviart» has collected the necessary information, structured it and published two reference books - the last one entitled «Art Galleries of Ukraine. Art Infrastructure" in 2007, where information on existing museums, galleries and CCAs was collected. Thus, as of 2007, there were 105 institutions across the country, of which 63 were in the capital (this included galleries, art centers and art salons). Separately in the catalog were indicated the centers of contemporary art located in the capital: «PinchukArtCentre», «Soviart», the Center for Contemporary Art at NaUKMA, «I-Gallery», as well as two in Western Ukraine: «Dzyga» - cultural and artistic center in Lviv and the Center of Contemporary Art in IvanoFrankivsk [1]. The tendency is quite positive, as of 2020 there were already about 250 galleries in Ukraine. However, the situation was such that their territorial distribution is uneven - in the capital and cities such as Lviv, Odessa, Kharkiv there is a large number of galleries, and in smaller cities there is almost no permanent platform for art presentation. Now «Soviart» is preparing for publication another collection-reference book «Art Infrastructure in Ukraine», continuing marketing and publishing projects.

Looking back to the early 1990s, we see that it was a period of socio-economic crisis, when state institutions ceased to function or underwent transformations. The formation of the first galleries was 
an initiative of individuals close to the artistic process. It was then that art critics and artists came together to create their own exhibition spaces. Initially, it happened on an amateur level, in the basements. But gradually galleries became legalized, legal entities with a bank account, contracts and so on. Most of them acquired the status of a public organization in Ukraine at that time the Law «On Public Organizations» was already in force; the process of legal registration of all public associations of Ukraine began in September 1990 with a resolution of the Presidium of the Verkhovna Rada of the Ukrainian SSR «On the Procedure for Registration of Public Associations», which facilitated the legitimacy of informal associations and forced state-owned organizations to revise their status - within the non-governmental third sector, which expanded the possibilities of galleries, including the tax-free sale of works of art from their own collections. In the 90s, many followed this path. In addition, the first institutions were forced to undertake other activities in order to survive and to thank for the premises provided by the city or district. They helped to organize district holidays, children's drawing competitions, to organize children's studios in their space, etc. Thus, at the first stage, they were forced to take over the functions of houses of culture, engaged in multicultural activities.

In the context of Soviart's program activities, the Ukrainian project at the $51^{\text {st }}$ Venice Biennale (2005) became important, when V. Khamatov was appointed its commissioner. The audience was introduced to M. Babak's project «Your Children, Ukraine», organized by the Ministry of Culture and Tourism of Ukraine. O. Tytarenko - one of the two curators - in the introductory article to the catalog notes: «The concept of our Venice project:» Do not shout about the whole world - tell about your village». The whole global world consists of individual villages. And it would be insanely unfortunate to lose this infinite variety, the luxury of nuances, dialects, sounds, tastes and aromas...» [10, p. 8].

Since the second half of the 1980s, the festival movement in Ukraine has become really powerful phenomenon. First of all, it was about rock music, but the vi- sual arts were not left out. An example is the International Festival «Spring Wind», founded in 1996, which included a number of events. Among the project partners were the Association of Art Galleries of Ukraine and the Center for Contemporary Art «Soviart». It was a festival of landart, the concept of which was to saturate the eternal and flowing landscape with objects that would complement the landscape and emphasize its uniqueness. The festival became a unique event, it boldly incorporated new ideas into the development of contemporary art in Ukraine [2, p. 4].

In 2012, with the participation of CCA «Soviart» and the Association of Art Galleries of Ukraine, the project «Communication XXI» took place and its main purpose was to highlight the leading trends in contemporary art of Ukraine. It was presented by a largescale exhibition at the Central House of Artists as part of the First Kyiv International Biennial of Contemporary Art (part of the exhibition consisted of works from the collection of CCA «Soviart»). The exhibition presented art works of 100 Ukrainian artists, whose names were associated with the formation of the main trends in contemporary Ukrainian art — from the 1950s to the present (2013), special group of experts was created to select these art works [3].

During the years of its activity since 1987, CCA «Soviart» has formed a large collection of works. The authors of artworks belonged to the non-conformist trend, which gave the opportunity to have a systematic idea of the contemporary visual art development in Ukraine. The works of the collection were digitized and presented in the register and catalog. In addition, CCA supported research activities, the field of interest - Ukrainian art of the last hundred years. An example is the monograph of Doctor of Arts L. Smyrna «Century of Nonconformism in Ukrainian Visual Art» (2017).

Realizing the need to share knowledge and experience, Soviart, together with the National Academy of Fine Arts and Architecture, founded the School of Art Management, which operated from 2004 to 2012. At the level of state-building initiatives, CCA joined the development of draft laws and participated in expert council of working groups of the Ministry of Cul- 
ture of Ukraine. In addition, it provided consulting work in the field of art management, contributing to the successful operation of corporate collections in Ukraine and abroad, museums, foundations, galleries and institutions of the «third sector» of culture.

Conclusions. Summing up, we noted that in the development of contemporary Ukrainian art CCA «Soviart» has acted as an alternative institution to the conservative public sector of culture. It initiated new forms of art management, a project approach in presenting new formats of Ukrainian art, expanding intercultural communication by signing cooperation programs, developing new forms of partnership between public and private sectors, including multicultural, creating a successful model of private art institution in the field of visual arts. Over the years of its existence, CCA «Sovi- art» has held more than 400 exhibitions; some of them have represented Ukrainian art abroad - in the United States, Georgia, Estonia, Germany, Denmark, France, UAE and Italy. Cooperation with Denmark, namely with the twin-city of Kyiv, Odense, proved to be especially productive. In 2005, CCA was a direct participant in the presentation of the Ukrainian national project at the Venice Biennale.

There is an example of an institution that is engaged in multifunctional activities and has a wide range of professional interests. In the conditions of the collapse of the USSR, the appearance of CCA «Soviart» in 1987, which worked immediately on the Western model, had the great importance for the further development of art infrastructure and contemporary art in Ukraine.

\section{Мітература}

1. 3бір.: Художні галереї України. Артінфраструктура. Совіарт. 2007. - 112 с.

2. Зінченко К. Філософія вітру.: кат. фест. Експрес-поліграф. Київ. - 21с.

3. Кат. аукц. Комунікація XXI 2013. упоряА. кат. М. Бабачук, А. Васильєва

4. Кат. V Міжнародний фестиваль, Совіарт. 2000.- 136 с.

5. Кат. 21 погляд. Совіарт. Молодь.1989. - 94 с.

6. Скмяренко Г. : кат. Українське малАRTство (60-80 рр.) - Київ : Мамменс Богтріккері А/C, 1990. - 142 с.

7. Смирна $\Lambda$. Століття нонконформізму в українському візуальному мистецтві. - Київ: Фенікс, 2017. - 480 c.: is.

8. Совіарт. URL: https://arts.in.ua/firms/f/52_soviart/

9. Титаренко О. Аіти твої, Україно : кат. мист. проєкту України на 51-й Венеційській бієнале - Київ : ПЦ. Інтертехномогія, 2005. -78 с.

10. Хаматов В., Святченко С. : кат. 1-й Сов.-Амер. выст. - Киев, СССР: Совиарт, 1988. - 35 с.

11. Хаматов В. Аля інтерв'ю з автором статті.

12. Хаматов В. Культурні герої - 2002 : кат. Фест. - Київ : Гнозис, 2002. -159 с.

\section{References}

1. Zbir.: Hudozhni galereyi Ukrayiny`. Artinfrastruktura. Soviart. 2007. - $112 \mathrm{s.}$

2. Zinchenko K. Filosofiya vitru.: kat. fest. Ekspres-poligraf. Ky`yiv. 21s.

3. Cat. aukcz. Komunikaciya XXI 2013. uporyad. kat. M. Babachuk, A. Vasy`l'yeva

4. Cat. V Mizhnarodny `j festy`val`, Soviart. 2000.- 136 s.

5. Cat. 21 poglyad. Soviart. Molod'.1989.- $94 \mathrm{~s}$

6. Sklyarenko G. : kat. Ukrayins`ke malARTstvo (60-80 rr.) - Ky`yiv : Mammens Bogtrikkeri A/S, 1990. - $142 \mathrm{~s}$. 
7. Smy`rna L. Stolittya nonkonformizmu v ukrayins`komu vizual`nomu my`stecztvi. - Ky`yiv: Feniks, 2017. - 480 s.: il.

8. Soviart. URL: https://arts.in.ua/firms/f/52_soviart/

9. Ty`tarenko O. Dity` tvoyi, Ukrayino : kat. my`st. proyektu Ukrayiny` na 51-j Venecijs 'kij biyenale Ky`yiv : PCz. Intertexnologiya, 2005. - $78 \mathrm{~s}$.

10. Khamatov V., Svyatchenko S. : kat. 1-j Sov.-Amer. vыst. - Ky`ev, SSSR: Sovy`art, 1988. - 35 s.

11. Khamatov V. dlya interv'yu z avtorom statti.

12. Khamatov V. Kul`turni geroyi - 2002 : kat. Fest. - Ky`yiv : Gnozy`s, 2002. -159 s.

\section{Иуговская А. Э. Институционахьное развитие современного искусства в Украине.} Аеятемьность ЦСМ "Совиарт"

Аннотация. На пороге третьего десятилетия XXI века мы видим активизацию Аеятельности арт-институций в Украине. Мы уже успели привыкнуть к Аостаточно большому их количеству и к многообразию направленности их деятельности, однако нужно вспомнить, что еще совсем недавно - в конце 1980-х - в начале 1990-х годов - их не было вовсе, речь идет именно о независимых, негосуАарственных учреждениях. Пионером в этой области стал Центр современного искусства «Совиарт» - первая в Украине независимая арт-институция, которая значительным образом повлияла на становление и дальнейшее развитие современного искусства. ЦСИ «Совиарт» изначально работал по западной модели. Он занимается мультифункциональной деятельностью и имеет широкий круг профессиональных интересов, которые всесторонне проанализированы в статье. Они включают в себя, в том числе и научную деятельность, результатом которой стало появление больше Авадцати исследований в области украинского искусства, как современного, так и всего XX века.

В статье рассмотрен опыт проведения выставок, арт-фестиваяей и художественных проектов, как в Украине, так и за ее пределами. Описан беспрецедентный, на тот момент, опыт проведения в Украине «Советско-Американской» выставки, в которой принимала участие стана западного, капиталистического мира - США. Впервые при создании выставки в нашей стране была проведена активная рекламная кампания, что включало издание, как сопроводительной Аитературы, так и рекламной продукции с фирменным моготипом. Также был применен принцип «тура» - выставка была показана в разных городах Украины, а также в Аругих советских республиках и США. Исследованы примеры успешного международного сотрудничества, комлаборации с Аругими институциями и посольствами, что послужило налаживанию культурного Аиалога с Аругими странами. На ее примере, выяснены обстоятельства, при которых происходило зарождение негосударственных художественных учреждений в условиях распада СССР и образования независимой Украины.

Ключевые слова: Арт-институция, деятельность центра современного искусства «Совиарт», современное искусство, арт-проект, выставка, арт-фестиваль.

\section{Ауговська А. Е. Інституційний розвиток сучасного мистецтва в Украӥні.}

\section{Аіямьність ЦСМ «Совіарт»}

Анотація. На порозі третього десятиліття XXI століття спостерігається активізація діяльності артінституцій в Україні. Вже звичними Аля нас $€$ їхня численність та розмаїття напрямків Аіяльності. ОАнак треба зауважити, що наприкінці 1980-х вони перебували на стаАії становлення. Піонером у цьому процесі став Центр сучасного мистецтва (ЦСМ) «Совіарт» - перша в Україні незалежна артінституція, яка суттєво вплинула на становлення й подальший розвиток сучасного мистецтва.

У нашому дослідженні всебічно проаналізовано діяльність ЦСМ, розглянуто досвіА проведення виставок, артфестивалів та мистецьких проєктів як в Україні, так і поза їі межами. АосліАжено приклади успішної міжнародної співпраці, колаборації з іншими інституціями та посольствами, що сприяло налагодженню культурного Аіалогу з цими країнами. На прикцаді ЦСМ «Совіарт», простежено за яких обставин відбувалося зародження недержавних мистецьких установ у час розпаду СРСР і здобуття Україною незалежності.

Ключові слова: артінституція, Аіяльність Центру сучасного мистецтва «Совіарт», сучасне мистецтво, артпроєкт, виставка, артфестиваль. 